Faustina Doufikar-Aerts

\title{
Gog and Magog Crossing Borders: Biblical, Christian and Islamic Imaginings
}

In the realm of eschatology, the history of the apocalyptic peoples Gog and Magog is a world in itself. The Gog and Magog theme plays a role in the eschatological tradition of all three Abrahamic religions. This article revolves around the theme of "crossing borders" - geographical, religious, and temporal borders - and investigates the development and dissemination of this wide-ranging motif in medieval literary as well as religious traditions. It considers the key stages in the evolution of the written testimonies of this motif and its pre-modern afterlife. A detailed analysis of four texts in particular will illustrate the intertwined character of the Gog and Magog motif within the tradition of Alexander the Great and Jewish, Christian and Islamic traditions and eschatology. ${ }^{1}$

\section{Sources and Transmission}

The reconstruction of the origins of the Gog and Magog motif starts with its first occurrence in extant written tradition. It is of significance that the initial manifestation of the names Gog and Magog (with variations) can be found in sacred texts, namely in a number of biblical books. Genesis (Gen. 10:2-4) names the sons (and some of the grandsons) of Japheth: "The sons of Japheth: Gomer, Magog, Madai, Javan, Tubal, Meshech, and Tiras. (3) And the sons of Gomer: Ashkenaz, Riphath, and Togarmah. (4) And the sons of Javan: Elishah, Tarshish, Kittim, and Dodanim."2 The names on this list are the ancestors and forefathers of tribes, as is made clear in Gen 10:5: "From these the coastland peoples spread out through their lands, each according to his own language by their own families, in their nations."

Locating these tribes both spatially and temporally became a subject of special interest in the nineteenth century. The supposed habitats of these tribes start turning up on topographical maps of the ancient biblical world. One example is the map in An Historical Textbook and Atlas of Biblical Geography by Lyman Coleman, entitled The World as known to the Hebrews according to the Mosaic account. ${ }^{3}$ In this visual representation, the relevant peoples are shown in the region between ancient

1 This article confines itself to this thematic subject matter. For a full study of Gog and Magog I refer to Bøe, Gog and Magog, as well as to Van Donzel and Schmidt, Gog and Magog.

2 Biblical citations here are according to the Lexham English Bible (LEB) or NIV, New International Version. These names are also mentioned in Chronicles 1:5-7, but with "Rhodanim" instead of "Dodanim".

3 Coleman, A Historical Textbook and Atlas of Biblical Geography, 34.

כ Open Access. (c) 2020 Faustina Doufikar-Aerts, published by De Gruyter. (c) BY-NC-ND This work is licensed under the Creative Commons Attribution-NonCommercial-NoDerivatives 4.0 License.

https://doi.org/10.1515/10.1515/9783110597745-015 
Thrace, Asia Minor, the Caucasus and Persia. Coleman's map shows how much attention academics, in particular scholars of the Bible, paid to identifying the tribes mentioned in Genesis 10.

Other passages, both in the Old and the New Testament, also refer to Gog and Magog, namely the passages in Ezekiel (38-39) and in Revelation (20). In Ezekiel 38:1-6 we find a prophecy directed against Gog and other tribes:

And the word of Yahweh came to me, saying (2) 'Son of man, set your face toward Gog of the land of Magog, the head leader of Meshech and Tubal, and prophesy against him. (3) And you must say, 'Thus says the Lord Yahweh: Look! I am against you, Gog, the head leader of Meshach and Tubal, (4) and I will turn you around, and I will place hooks in your cheeks, and I will bring you out and all of your horses and horsemen fully armed, all of them, a great crowd, holding a shield, and small shield, and holding swords, all of them. (5) Persia, Cush, and Put are with them, all of them, with a small shield and helmet. (6) Gomer and all of its troops, Beth Togarmah, the remote areas of the north, and with all of its troops and many peoples with them'.

After further prophetic descriptions of Gog's army and progress, Ezekiel 38:14-16 continues with predictions, particularly about the multitude of Gog's horsemen and their coming from the North:

Therefore prophesy, son of man, and you must say to Gog, 'Thus says the Lord Yahweh: 'Will you not realize on that day when my people Israel are dwelling in safety, (15) and so you will come from your place, from the remote areas of the north, you and many people with you, horsemen all of them, a great crowd and a vast army, (16) and you will advance against my people Israel like a cloud covering the land; it will be in the last days, and I will bring you against my land, so that the nations know me, when I show myself holy through you before their eyes, O Gog!'

In continuation a third passage in Ezekiel 38:18-20 with predictions, particularly about the multitude of Gog's horsemen and their coming from the North:

'And so then in that day, on the day of the coming of Gog against the land of Israel', declares the Lord Yahweh, 'My rage will come up in My anger. (19) And in My passion, in the fire of My wrath, I spoke that certainly on that day a great earthquake will be on the land of Israel. (20) And the fish of the sea and the birds of the heaven and the animals of the field and all of the creeping things that creep on the earth and all of the humans who are on the surface of the earth will shake at My presence; and the mountains will be demolished, and the steep mountain sides will fall, and every wall on the earth will fall.'

Subsequently, Ezekiel 39:1-3 reinforces the element of the remote areas of the north:

And you, son of man, prophesy against Gog, and you must say, 'Thus says the Lord Yahweh: 'Look! I am against you Gog, the head leader of Meshech and Tubal, (2) and I will turn you around, and I will drag you along, and I will bring you up from the remote areas of the north, 
and I will bring you against the mountains of Israel, (3) and I will strike your bow from your left hand, and your arrows from your right hand I will cause to fall.'

Ezekiel 39:6 specifically mentions Magog:

And I will send fire against Magog and among the people inhabiting the coastlands in safety, and they will know that I am Yahweh.

The last predictions in Ezekiel 39:11 speak about the burial of the hordes of Gog:

And then on that day I will give to Gog a grave there in Israel, The Valley of the Travelers, east of the sea, and it will block the travelers and Gog and all of his hordes they will be buried there, and they will call it the Valley of Hamon-Gog [= God's multitude].

In the New Testament, Gog and Magog appear in Revelation (20:7-8) in a passage on the defeat of Satan:

(7) When the thousand years are ended, Satan will be set free from his prison (8) and will go out to deceive the nations which are in the four corners of the earth, Gog and Magog, to gather them for battle. Their number is like the sand of the sea.

From the above, we can observe that the meaning of the names is not stable, but ambiguous. In these early scriptures, Gog and Magog are not always mentioned together. Magog can refer not only to an individual, but also a tribe, and even to the abode of Gog. ${ }^{4}$ We may assume, however, that Gomer and Magog, originally the names of the sons of Japheth, provided the basis for the names Gog and Magog that were later used to refer to the tribes of their supposed descendants. The above passages signify the beginning of the long-term presence of Gog and Magog in the minds and consciousness of religious communities. In Late Antiquity, the Gog and Magog motif spread from the Middle East into North Africa and Europe and, later on, into the Islamic world. There is a number of distinctive elements in the above passages on Gog and Magog, such as the vast horde of warriors mounted on horseback that is described as a cloud covering the land, the motif of Gog and Magog described as being as numerous as "the sand of the sea", their release after a thousand-year period as an invasion from the north, and walls crumbling down to the ground. These elements will reappear again and again in various combinations in later stages of the transmission of the Gog and Magog motif.

A key role in the development of the Gog and Magog theme after its first appearances in the Old and New Testaments seem to have played a series of apocalyptic texts, produced mainly in the various seventh-century Syrian Christian communities. ${ }^{5}$ These provided an important addition to the theme: the fact that Gog and Magog were sealed off from the world by Alexander the Great behind a barrier with a

4 It may have been considered a prefix ma $(/ \mathrm{mem})$ indicating a nomen loci with the implication of "the place where". 
gate that would break down at the end of time. These texts, in particular the Revelationes by Pseudo-Methodius, spread throughout Christian medieval Europe, mostly as part of histories about Alexander the Great, ${ }^{6}$ because the Gog and Magog episode based on Pseudo-Methodius became part of the Byzantine/Greek recensions $\varepsilon$ and $y$ of the Alexander Romance by Pseudo-Callisthenes that are currently dated to the late ninth and probably post-ninth century, respectively. ${ }^{7}$ It also found its way into the Historia de Preliis $\mathrm{J}^{2}$, a twelfth-century Latin recension of the Alexander Romance. ${ }^{8}$ Moreover, the Latin translation of Pseudo-Methodius' text also attained great popularity in Europe, independantly. ${ }^{9}$

The motif of the enclosure of Gog and Magog and the associated End Times' scenario came to play a prominent role in the Islamic tradition, as I will demonstrate below. In Arabic, Gog and Magog first appear as "Yājūj wa-Mājūje" in the Qur'an. ${ }^{10}$ As an illustration of the expansion and scope of this motif across time and space, I would like to draw attention to an early nineteenth-century Javanese poem that includes an End-Time character named Juja-Makjuja, whose name obviously derives from the Arabic form of Gog and Magog, Yājūj wa-Mājūj. According to the poem, the angel (!) Dulkarnèn, following divine commands, tied up Juja-Makjuja with a hundred ropes. However, the latter managed to free himself by licking the cords with his tongue. Eventually, he was put in chains that he could not lick away due to the prayers of the faithful. ${ }^{11}$

This poem from the remote Indian archipelago echoes motifs from what I have coined "the Dhū 'l-Qarnayn tradition". ${ }^{12}$ The angel's name in the Javanese poem, Dulkarnèn, is evidently rooted in the Arabic cognomen Dhū 'l-Qarnayn. In the

5 It concerns the Glorious Exploits of Alexander, the Homily and Revelations, to which we will return in the below.

6 Revelationes or Apocalypse by Pseudo-Methodius. For its influence on Christian eschatology see Garstad, Apocalypse, ix-xii. The translation in Garstad of the Greek and Latin translations of the original Pseudo-Methodius in Syriac derive from the edition by Aerts and Kortekaas, Die Apokalypse. 7 Aerts, "Gog, Magog, Dogheads," 29-30 favours a date for $\varepsilon$ of "the (late) 9th century or even early 10th century" and argues that $y$ originated "considerably later". Georg Trumpf, in "Pap. Berl. 21266," 86, estimates that the composition of $\varepsilon$ occurred in the eight/ninth century. Jouanno, Naissance et métamorphoses, 338 deems a later date than the late ninth century improbable. Her findings are supported by Moennig, "Alexander the Great," 167.

8 See Pritchard, The History of Alexander's Battles, 8. It was also translated into Arabic and twice into Hebrew. See Van Bekkum, Hebrew Alexander Ms. London, 119 and Van Bekkum, Hebrew Alexander Ms. Paris, 77. In the Hebrew texts the names, Gog and Magog, are not mentioned, but the description fits the characteristics of Pseudo-Methodius.

9 Aerts and Kortekaas, Die Apokalypse, 31-35. Also see Cross, "The Earliest Allusion in Slavic Literature to the Revelations of Pseudo-Methodius."

10 Q 18:94 and Q 21:96. A variant reading is Yā’jūj wa-Mā’jūj.

11 My paraphrase from the description by Wieringa, "Juja-Makjuja as the Antichrist," 135-136.

12 This tradition was classified and analysed as part of Alexander Magnus Arabicus, where I gave an overview of the Alexander tradition in the Arabic and Islamic world, linked to the sacred character Dhū 'l-Qarnayn, see Doufikar-Aerts, Alexander Magnus Arabicus, chapter 3, 135-193. 
Islamic tradition, the identity of the man designated by the epithet Dhū 'l-Qarnayn - the Two-Horned - in the Qur'an (18:83) has been much discussed. A rather obscure, but peculiar view is that he might be an angel. Ibn Kathīr (c. 1300-1373) and al-Damiri (1344-1405), for instance, transmit the following in the name of the second caliph, 'Umar ibn al-Khattāb, when they wrote: "However, the most unlikely opinion thereof was that he [Dhū 'l-Qarnayn] was an Angel. This was said after the Commander of the Faithful, 'Umar Ibn Al-Khattāb, who heard a man calling another man, saying: 'O Dhū 'l-Qarnayn!' He ['Umar] said: Leave it! Was it not enough for you to name yourselves after the Prophets that you give names after those of the Angels?"13

This eccentric hadith is probably the source for Dulkarnèn and his angelic status in the poem. According to the interpretation of Edwin Wieringa, who analysed this poem both thematically and structurally, "the Javanese versions of the story of Alexander from the court of Surakarta ends with the episode of Sultan Iskandar's building an iron wall to keep out Gog and Magog". ${ }^{14}$ However, "he warns his followers, this barricade will fall when the Day of Judgement is near, because it will be licked by the sharp tongue of Makjuja" ${ }^{15}$ In the below I will construe the motif of the licking tongue. This first instance here is to demonstrate that the Gog and Magog motif in the Islamic world came to reach the far-east parts of the world.

Similarly, in another part of the world, in Mali, Gog and Magog can be found in a vita entitled Qișșat Dhī l-Qarnayn, “the Story of Dhū 'l-Qarnayn”. This Qișșa, preserved in an eighteenth-century manuscript from Timbuktu, was discovered and edited only recently. ${ }^{16}$ The Islamic epithet Dhū 'l-Qarnayn became attached to Alexander the Great at an early stage of Islamic literary and religious history. ${ }^{17}$ In some versions of the Story of Dhū 'l-Qarnayn, the protagonist was called al-Iskandar Dhū 'l-Qarnayn. At the beginning of an episode describing the building of the wall to keep out Gog and Magog, we read in the Malinese copy: “And he [Dhū 'l-Qarnayn] traveled to the site of Gog and Magog, located in between a pair of sleek, high and towering mountains; any bird that would fly over it would not have a chance to survive." 18 The passage refers to the description of Gog and Magog in the Qur'an 18:93, but it gives more details. A number of manuscripts with texts similar or re-

13 Ibn Kathir, Al-Bidāya, 95. Slightly different in Damīrī, Hayat al-Hayawān, ed. Houtsma, 17: “And because of that, when 'Umar ibn al-Khattab, may God be pleased with him, heard a man calling: $\mathrm{O}$ Dhü' l-Qarnayn!, he ['Umar] said: Have you finished now with the names of prophets and are you moving up to the names of angels?"

14 Sultan Iskandar refers to Alexander the Great.

15 Wieringa, "Juja-Makjuja as the Antichrist," 135-136, is citing Ricklefs, The Seen and Unseen Worlds, 51-52, 97.

16 The Arabic text of the manuscript was edited diplomatically, including a conversion into Modern Standard Arabic with a French translation by Bohas and Sinno, Le Roman d'Alexandre.

17 See Doufikar-Aerts, Alexander Magnus Arabicus, 135, and "Alexander in Medieval Arab Minds." 18 The passage refers to the description of Gog and Magog in the Qur'an 18:93. This will be discussed in more detail in the below. 
lated to the Story of Dhü 'l-Qarnayn were circulating in North Africa and Spain from the ninth century onwards. ${ }^{19}$ However, the motif did not only travel in textual form from the Middle East to Timbuktu and Java, it also had a vivid existence in visual representations.

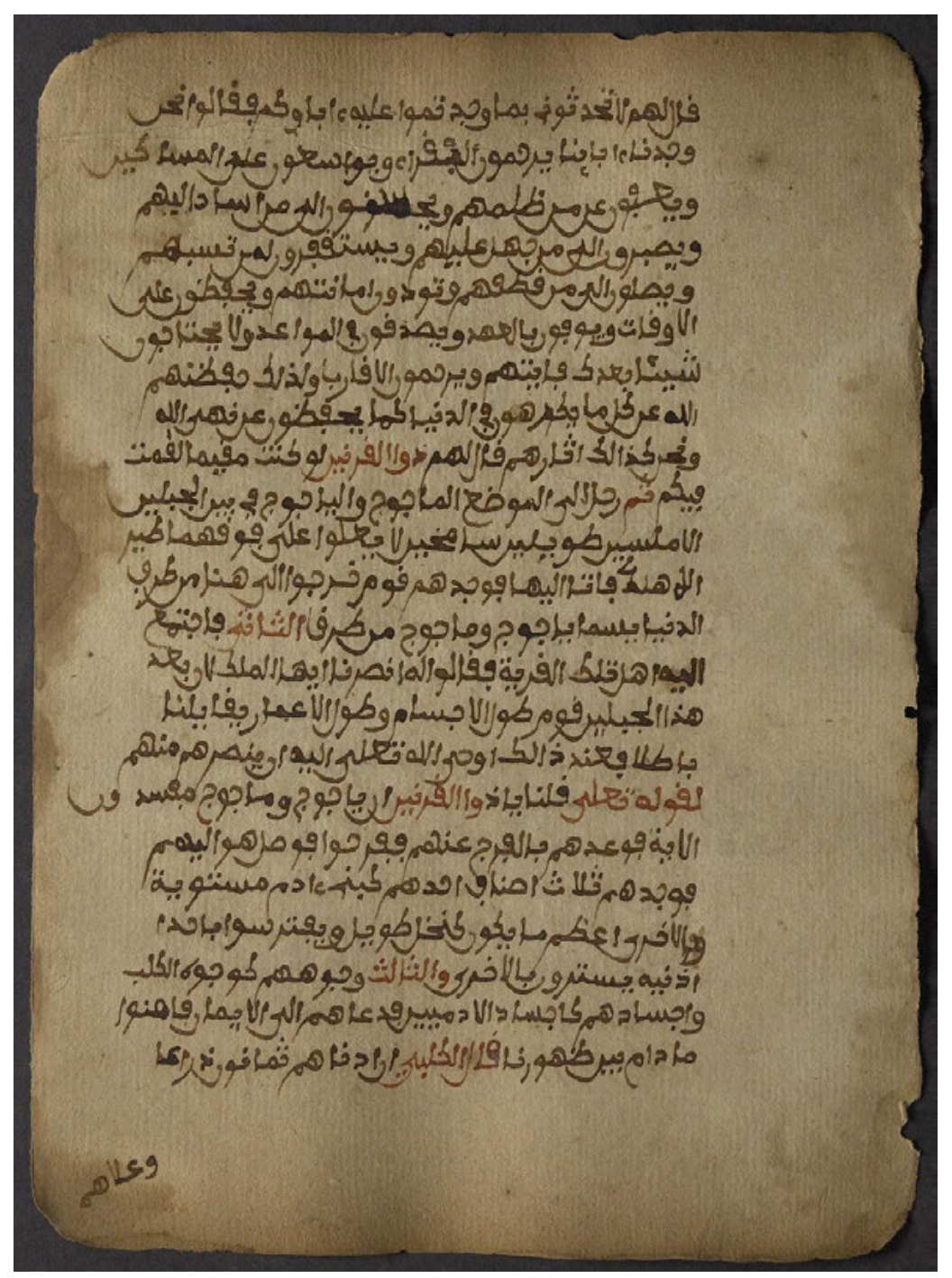

Fig. 1: Page 19 in Ms. Kitāb Qișșat Dhū (!) al-Qarnayn. The manuscript from the Mamma Haidara Commemorative Library in Timbuktu has no page numbers and is dated to $1157 \mathrm{AH}=1744 \mathrm{AD}(\odot$ Mamma Haidara Collection).

19 See Doufikar-Aerts, Alexander Magnus Arabicus, 50-58, and Zuwiyya, Islamic Legends, 47-48. 
The great impact of the Gog and Magog motif in medieval Europe and the Islamic world is witnessed by their frequent appearance in cartography. Medieval maps of the world frequently indicate the abodes of Gog and Magog and the place of the barrier against them. Gog and Magog are sometimes identified with nations such as Ung and Mongol, Goth and Magoth, the Scythians, Turks or Tatars. ${ }^{20}$ For centuries their presence in the remote corners of the world was a recurrent element on maps, a phenomenon extensively described by Andrew Gow. With the increasing empirical knowledge over time about geographical dimensions, the outskirts of the world on maps, shifted further and further away and with them the abodes of Gog and Magog. ${ }^{21}$

By examining several key extant maps in a roughly chronological order, we can observe that the wall or gate of Gog and Magog was a common constituent of cosmographical presentations. The eleventh-century Isidorian Mappa Mundi, made by an anonymous map maker, was based on Isidore of Seville's (560-636) schematic tripartite division of the world, the diagrammatic "T and $\mathrm{O}$ model" in Book fourteen, chapter two of his Etymologiae. It clearly shows a mountain-range with a closed gate to the west of the Caspian Sea, in the extreme north of Asia as it was imagined, which, like on other such maps, is presented on the left. ${ }^{22}$

The unique Anglo-Saxon Mappa Mundi from the Cotton manuscript collection, which dates to the end of the tenth century or slightly later, does seem to be a stylistically independent creation in that it does not follow a known cartographic model; it has an almost square shape and Gog and Magog are situated in the far north on the western shore of the Caspian Sea, located on the left of the map. ${ }^{23}$ There is a range of mountains depicted in their territories, but Gog and Magog are not clearly enclosed behind a barrier or gate.

The Sawley Map, also called the World Map of Henry of Mainz, dates from circa 1110; it has an oval form and is oriented with east at the top. In the north, on the left, it shows Gog and Magog plainly enclosed in a square, with a wall constituting the south of the square and the other sides formed by a mountain range.

On the detailed Psalter Map dating from between 1221 and 1250, a long wall with gate is prominently visible. This romanesque art style map, which is ruled by the Christian religious world scheme, with Christ at the head of the image, also situates the enclosure in the north-eastern part of the world, similarly as on other such maps presented on the left. ${ }^{24}$

20 For more suggestions of identification see Bøe, Gog and Magog, 88-99.

21 See the maps in Gow, "Excerpt from Gog and Magog" and note 28.

22 Bayerische Staatsbibliothek, Ms. Clm 10058, fol. 154v. Images and a survey of world maps depicting the Wall of Gog and Magog can be found in Gow, "Excerpt from Gog and Magog” on http:// www.myoldmaps.com/early-medieval-monographs/gog-and-magog-on-mappaemund.pdf.

23 British Library, Cotton MS Tiberius BV.

24 British Library, Add MS 28681. For details see: http://www.myoldmaps.com/early-medievalmonographs/223-the-psalter-mappamundi/223-psalter.pdf. 
One of the most famous medieval maps is the Ebstorf Mappa Mundi from circa 1234. ${ }^{25}$ The enclosure of Gog and Magog is situated on the eastern shore of the Caspian Sea - that is, the opposite shore to where both the Isidorian and Cottonian maps placed it - and shown as a square with a wall on the land side and mountains on the sea-side, similar to the Sawley Map's representation. Remarkably, Gog and Magog are depicted as cannibals.

The latter two maps, and many others for that matter, are constructed according to a religiously defined pattern. At the top of the map, namely the ultimate eastern part of the world, they show Christ, on the Psalter Map also flanked on the left and the right side by angels. Below his hands lies paradise, which is thus located in the east.

Even centuries later, Gog and Magog were still represented on maps, such as on Gerard Mercator's mappa mundi from 1569 intended ad usum navigantium, for the use of sailors. ${ }^{26}$ Here the two nations are situated on opposite sides of a mountain range: the nation on the left is described as Mongul quae a nostris Magog dicitur ("Mongul, which we call Magog"), and the area to the right of the mountains is labelled Ung quae a nostris Gog dicitur, "Ung, which we call Gog”. ${ }^{27}$

Even on early modern maps based increasingly on empirical data, such as Sanson's double hemisphere map of the world from 1691, we can find Mongal et Magog, directly beneath the Polar circle in the farthest north-east part of the globe. ${ }^{28}$

The abodes of Gog and Magog were not only to be found on maps from medieval Christian Europe; they were also depicted on Islamic mappae mundi. The oldest map of this kind is the mappa mundi by Abū 'l-Qāsim Ibn Ḥawqal, an Arab scientist and traveler of the tenth century. He based his maps and his travel reports on his own experiences, and probably also on the works of Ptolemy (second century CE). The map was part of his geographical work, Șūrat al-Ard ("Image of the Earth"), the oldest extant manuscript of which dates from $1086 .{ }^{29}$ Ibn Hawqal's map

25 It was made sometime during the tirteenth century out of 30 goatskins. Unfortunately, it was destroyed in the bombing of Hanover in 1943, but has survived in several good facsimiles and photographs. See http://www.landschaftsmuseum.de/Bilder/Ebstorf/Ebstorf-neu_ganz-2.jpg.

26 He drew upon Marco Polo's travelogue, Il Milione, written about 1300.

27 Gerritsen, "Gog and Magog," 9: "On the top of the mountains lying north of Ung one can discern two tiny human figures blowing trumpets. The legend explains that they represent the bronze statues of two trumpet blowers which in all probability were erected here by the Tartars, in perpetual memory of the liberty they gained when they crossed over the highest of these mountains on their way to safer regions." The presence of trumpet blowers may have been understood otherwise at the time. It is possible that they were considered to symbolise the sounding of the seventh trumpet blown by the angel at the end of times, in Revelation 11:15-19.

28 Captioned: Description General du Globe Terrestre et Aquatique en Deux-Plan-Hemispheres. It was composed by Guillaume Sanson and published by H. Jaillot (Paris, 1674) and is currently being digitised as part of the collection of the Bibliothèque de France.

29 Topkapı Sarayı Müzesi Kütüphanesi, ms. A. 3346, fols. 3b-4. 
is oriented with south at the top, and he situated the "regions of Gog and Magog" in the northernmost part of the world.

Another example of an Islamic representation of Gog and Magog is the world map by al-Idrīsī. ${ }^{30}$ The map, known as Tabula Rogeriana, was created in 1154 at the court of Roger II, the King of Sicily. The map also has south at the top, but is less schematic and slightly more accurate than the map of Ibn Hawqal. All the same, it shows a considerable part of the world behind a mountain range in the most northern region as inhabited by Gog and Magog. Many copies of the map survive, including the Charta Rogeriana ("Weltkarte des Idrisi"), a horizontal elaboration of the map, in a "reconstruction" by Konrad Miller in $1927 .{ }^{31}$ The map, which is also situated south-north, depicts Gog and Magog enclosed by a prominent mountain range with fortifications, called the jabal Qüfäia. ${ }^{32}$ Between the range's northern mountains is a gate with the Arabic caption in Latinised script: sadd $\underline{d} \bar{\imath}$ 'l karnajin, al musamma bi al rad[ ] (radm?), "The Barrier of Dhū 'l-Qarnayn, called the Rampart". Miller here used the very words of the Qur'an verses (18:94.95), sadd and radm, to describe the wall.

Further, on a fifteenth-century Iranian world map, preserved in the anonymous work Mojmal al-Tawārīkh wa 'l-Qeșaș ("Compendium of Histories and Narrations"), it is amazing to see that on the left side a considerable part of the globe is confined by a huge wall with gate. ${ }^{33}$ According to the caption this is the Wall of Gog and Magog. It is situated in the north-east quarter of the world, on the left of the map which is again oriented south-north. On the map's right side, which shows the southern shore of the Mediterranean, the formidable lighthouse of Alexandria stands on the right bank of the Nile. Its construction was generally attributed to Alexander the Great, but in fact it was built after his death during the Ptolemaic period. The prominence given to these constructions, and their dimensions, which are completely out of proportion, is symbolic for their power and dominance. The way in which the edifices are presented gives the impression that Alexander was responsible for the

30 Abū 'Abd Allah Muḥammad ibn Muḥammad ibn Idrisī al-Qurțubī (1100-1166); the Tabula Rogeriana was part of his Kitāb Nuzhat al-Mushtāq fi Ikhtirāq al-Āfāq ("Book of Pleasant Journeys about Remote Regions”). The famous Cairo copy made by 'Alī ibn Ḥasan al-Hūfĩ al-Qāsimī in 1456 is preserved in Oxford's Bodleian Library, ms. Pococke 375 fol. $3 \mathrm{v}-4$. A digitised image can be found at http://bodley30.bodley.ox.ac.uk:8180/luna/servlet/detail/ODLodl 23 23 126595 142784:WorldMap?qvq=w4s:/what/MS.\%20Pococke\%20375; lc:ODLodl 29 29, ODLodl 7 7, ODLodl 6 6, ODLodl 14 14, ODLodl $\sim 28$, ODLodl $23 \sim 23$, ODLodl $\sim 1 \sim 1$, ODLodl $\sim 24 \sim 24 \& \mathrm{mi}=0$ \&trs=70\#

31 In the collection of the Library of Congress: https://www.loc.gov/resource/g3200.ct001903/? $\mathrm{r}=0.023,0.279,0.295,0.123,0$

32 Possibly Mount Qāf is meant here.

33 Mojmal al-Tawārikh, ms. pers. Cod. Heid. orient. 118, fols. 258b-259a, in the University Library of Heidelberg. http://dfg-viewer.de/show/cache.off?id=2\&tx_dlf\%5Bid\%5D=http\%3A\%2F\%2Fdigi.ub. uni-heidelberg.de\%2Fdiglit\%2Fcodheidorient118\%2Fmets\&tx_dlf\%5Bpage\%5D=522 [accessed 18 January 2020]. On the topic "wall versus gate with key!" see Doufikar-Aerts, Alexander Magnus Arabicus, 159-162. 
world's most significant buildings, with the only exception of the Ka'ba, which is situated in the middle.

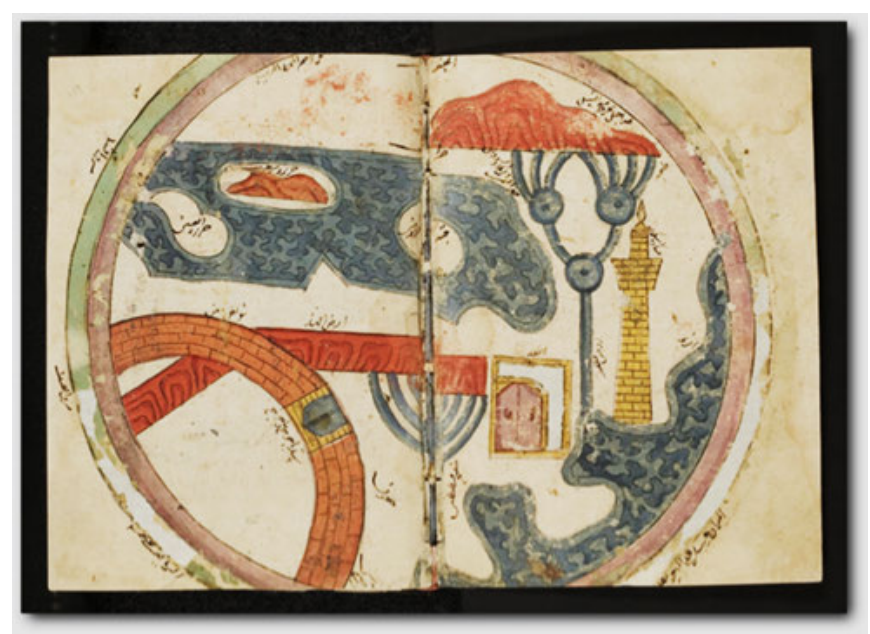

Fig. 2: Mojmal al-Tawārikh, ms. pers. Cod. Heid. orient. 118, fols. 258b-259a (@ Universitätsbibliothek Heidelberg)

The positioning and demarcation of Gog and Magog in medieval and pre-modern maps is telling. It points to the belief in the genuine confinement of the two nations, somewhere in terra incognita, or, to put it in allegorical terms, in "Magogistan". Moreover, the wide geographical and temporal range of these maps' production and the representations is striking evidence of the Gog and Magog motif's long-lived cultural importance.

In this regard it is interesting to examine what instigated this process of dissemination on the medieval world scale. It was briefly mentioned above that a number of Syriac Christian apocalyptic texts played a key role in the development of the Gog and Magog motif. Three of them, which are still extant today, were particularly influential: the anonymous Neșhāna dileh d-Aleksandrōs, the "Glorious Exploits of Alexander", also known (after Wallis Budge) as the Christian Syriac Alexander Legend. Subsequently, a verse version of mainly the same content appeared, the Memra d-Aleksandrōs - known as Homily or Discourse - attributed to Mār Yaqūb of 
Serūgh. ${ }^{34}$ A third influential text was the Apocalypse or Revelationes written by the author nowadays known as Pseudo-Methodius.

The first and second of these three texts were composed in the first half of the seventh century, around 628 and 636 respectively, preceding the advent of Islam in their region of origin. Pseudo-Methodius' work dates to the 690s, a decade indeed perceived as an apocalyptic time by many nations and religious communities of the Middle East. ${ }^{35}$ These apocalyptic texts all originated in the Syrian Christian communities as reactions to three different events that left indelible traces on the history of the region: the defeat of the Persian King Khosroes II by the Byzantine Emperor Heraclius in 628 , the conquest of Jerusalem shortly afterwards, in 636, by the new players on the world stage, the Muslims from the Arabian peninsula, and finally, around 692, the building of the Dome or the Rock in that city.

Whilst the texts are anonymous, two of them have been attributed to alleged authors. All three elaborated on the biblical information about Gog and Magog. In a manner of speaking, they excavated, and blew new life into, the role of Gog and Magog as a scourge of mankind at the end of times.

Apart from that, the Syriac tradition, beginning with the Neshāna, added a completely new element to the motif in the form of Alexander of Macedon, the ancient world conqueror. He becomes the builder of a barrier intended to prevent Gog and Magog, whom the composers or the interpreters of these texts linked to the Huns, from spoiling the earth and harassing its inhabitants. He supposedly built the enclosure with the assistance of three thousand smiths, and also travelled to the impassible Foetid Sea (Ôkěyânôs) - supposedly in the west - and to the place of sunrise. ${ }^{36}$

Alexander had been associated with fences before, above all in the work of Flavius Josephus. ${ }^{37}$ These barriers were variously located in the Caucasus: the Caspian Gates of Derbend and the Daryal Gorge in todays' Georgia. However, the Syriac apocalypses joined together elements that had not occurred in this combination before: Alexander the Great, the Biblical nations of Gog and Magog and the barrier that enclosed them, and eschatological predictions. Some scholars have assumed that this innovative element in the Neșhâna is bearing on a vision in the Book of Daniel 8:20-24, which was interpreted as a struggle between the Greeks (Alexander the Great) and the Persians that would end in the latter's defeat. ${ }^{38}$ Furthermore, the Neșhāna states that Alexander had horns on his head "wherewith he

34 Texts and translations of both in Wallis Budge, The History of Alexander the Great.

35 See Reinink, "Alexander the Great".

36 Wallis Budge, The History of Alexander the Great, 153-156 and 145-148, respectively. The Foetid Sea is the ocean, which according to cosmological perceptions surrounds the inhabited world.

37 Flavius Josephus, Bellum Judaicum, 7.7.4. See transl. by Thackeray, The Jewish War, 575.

38 (20) "The two-horned ram that you saw represents the kings of Media and Persia. (21) The shaggy goat is the king of Greece, and the large horn between his eyes is the first king. (22) The four horns that replaced the one that was broken off represent four kingdoms that will emerge from his nation but will not have the same power. (23) In the latter part of their reign, when rebels have 
might thrust down the kingdoms of the world". ${ }^{39}$ Alexander also attached an inscription to the gate in the wall he erected, which predicted that Gog and Magog would break loose on God's command at the destined Hour: this refers to the Hour at the end of time.

No less important is the fact that Alexander is presented as a forerunner of the Christian hegemony that will precede the end of time.

This demonstrates that the Syriac tradition of the seventh century elaborated on the biblical apocalyptic notices and worked out complete new dimensions, which formed the beginning of a new stage in the development of the Gog and Magog motif crossing borders.

This is of interest because the second important phase in the history of the Gog and Magog motif is its development in the Islamic tradition. I already mentioned above that Gog and Magog appear in two different Qur'anic verses under their Arabic name Yājūj-wa-Mājūj. ${ }^{40}$ In one of these passages, the building of the Wall of Gog and Magog is part of a set of related verses ( $Q$ 18:94-100) that, according to one interpretation, may be read as a parable. ${ }^{41}$ Although the character of the Qur'anic revelation leaves the narration (dhikr) ${ }^{42}$ more cryptic than the Syriac accounts, it is nevertheless evident that it includes many elements that we also encountered in the seventh-century Syriac apocalypses. In the Qur'an verses it is the ancient character, referred to as Dhū 'l-Qarnayn, the Two-Horned, who builds the barrier to enclose Yājūj-wa-Mājūj. Nevertheless, even without sharing names, the mutually shared traits of both figures are noticeable. The comparable events and references show similarities, without being identical. This observation was already made in the first centuries of Islam.

Early commentators on these verses and transmitters of Prophetic Traditions already suggested an association between the two. ${ }^{43}$ They may have recognised corresponding features, which made them suppose that the Two-Horned was to be identified with Alexander. In the Biography of the Prophet, its author, Ibn Ishāq (d. 767) states that he knows from the accounts of foreigners ( $a^{e} \bar{a} j i m$ ) that Dhū 'l-Qarnayn was a man from Egypt, designated as "the Greek", and that he was from the lineage of Yafeth, son of Noah. Further, Ibn Hishām (d. 828), the transmitter and revisor of Ibn Ishāq's Biography, adds that this person's name was al-Iskandar and that he

become completely wicked, a stern-faced king, a master of intrigue, will arise. (24) He will become very strong, but not by his own power. He will cause astounding devastation and will succeed in whatever he does. He will destroy the mighty men and the holy people."

39 Wallis Budge, The History of Alexander the Great, 146.

40 Qur'an 18:94 and 21:96.

41 Qur'an 18:83-100. Abdullah Yusuf Ali, The Holy Qur'an, 753.

42 Actually, the rendering of the word dhikr in the verse varies in translations: report, account, remembrance, story, history.

43 See Doufikar-Aerts, “Alexander in Medieval Arab Minds.” 
built the city of Alexandria, which was called after him. ${ }^{44}$ Although this allusion is just one of more suggestions he mentions, Ibn Hishām was likely one of the sources which instigated or corroborated the development of the identification of Dhū 'lQarnayn with Alexander the Great.

Whether Ibn Ishạa and Ibn Hishām were familiar with the Syriac tradition in the form in which it has come down to us cannot be determined with any certainty. However, it is clear that they or other traditionists were familiar with a version of it, because the recurrent descriptions of the features of Gog and Magog in Islamic writings did not derive from the Qur'an. The only characterisation in the Qur'an (18:93) is that Gog and Magog "spoil the earth" (mufsidūna fi al-ard).

Be that as it may, Alexander became part of Islamic tradition and primarily associated with Gog and Magog, and an eschatological narrative. Already before the ninth century the history and image of Alexander became intertwined with the characteristics of the Two-Horned and he was generally named al-Iskandar Dhū 'l-Qarnayn.

In the following, four texts of different genres will be considered that will serve to demonstrate the close connection of Gog and Magog and other eschatological phenomena with Alexander.

\section{Signs of the Hour in Pseudo-Așmaī}

According to Islamic eschatology, there are signs of the end of the world, often referred to as the Hour, al-Sä $a$. The signs warning of it are called ishārāt al-sāa $a$ ("Tokens of the Hour"), ashrāt al-sā'a ("Conditions of the Hour”), 'alāmāt al-sā'a ("Signals of the Hour"), and $\bar{a} y \bar{a} t$ al-sāe $a$ ("Signs of the Hour"). They are divided in major and minor signs. Some speak of ten major portents and another set of minor signs of the Hour. Other traditions mention seven major portents and up to one hundred minor signs. Major signs shared by many traditions include - apart from natural phenomena, such as fire, smoke and earthquakes - particular encounters, the release of al-Masīh al-Dajjāl ("the Antichrist"), Gog and Magog, the Beast, the Mahdī (Messiah), and the return of Jesus, son of Maryam (Mary). ${ }^{45}$

That Alexander became intertwined with the Qur'anic Dhū 'l-Qarnayn emerges particularly clearly if we look at Arabic translations of "secular" texts about Alexander from Syriac and Greek. The translation into Arabic of the Alexander Romance, a partly historical, partly legendary biography, was the source for Islamic historians' presentations of the history of Alexander. Almost without exception, the Qur'anic

44 Sīrat al-Nabī, Ibn Hishām, Fathi Anwar al-Danuli, Cairo (s.d.), 1.387. Also see above, the remarks about Alexander's reputation as the builder of the lighthouse of Alexandria.

45 See Haddad and Smith, "The Anti-Christ and the End of Time," 512-518. 
Dhū 'l-Qarnayn and the Gog and Magog episode came to form part of these historical accounts. ${ }^{46}$

The passage quoted below comes from a manuscript presenting the work, entitled "Biographies of the Kings and the History of the Persians and the Arabs" by the historian Pseudo-Așma ${ }^{i}{ }^{47}$ The text, which will be referred to here as Nihāya, is considered to date from before the year 850. The scene describes a dialogue in which Alexander questions the Brahmans, the Indian sages also known as the Gymnosophists or the "naked philosophers" in Greek literature. The story of the encounter with the Brahmans is a very well-known episode from the Alexander Romance. ${ }^{48}$ Pseudo-Așma'i gives it a special twist in his text. In addition to the regular, recurring parts of this episode, in this version Alexander also asks the Brahmans about the future of his realm.

Alexander said: 'Tell me, who will be reigning the kingdom after me?' The Brahmans answered: 'After you will reign the Mulūk al-Tawā'if [the petty kings] ${ }^{49}$, because you will appoint them over all the lands and the regions. ${ }^{50}$ Then, after them, the kingdom of Irān Shahr will transfer to the sons of Sāsān ${ }^{51}$ the son of King Bahman Isfandiyād, [=Esfandiyār] the son of Bishtāsaf [=Bishtasb] the son of King Luhrāsaf [=Lohrasb]. And he is [the same as] Bukht Nașr [Nebukadnezzar 1145-1114 B.C.E.] $]^{52}$, and they will reign for a very long period. Then God Almighty will give power in the neighbouring lands to the sons of Isma'îl, the son of Ibrāhim al-Khalil [the 'God's friend' Abraham], peace be upon them. They now live in the deserts and they feed upon meat and drink milk and they will be in power and conquer the land until the end of time. ${ }^{53}$

And Alexander asked: 'And how will they attain kingship?' They [the Brahmans] said: 'God Almighty will send to them a virtuous, God-fearing, devout, righteous and merciful man, who observes truthfulness and honesty. Rebukes by any critic do not distract him from the sake of God. 54

46 See Doufikar-Aerts, Alexander Magnus Arabicus, 26, 33-35, 38, 43, 46-48, 60, 68, 72 and chapter 3, 135-193. Several, mainly seventeenth-century manuscripts have surfaced, which contain a redaction of Pseudo-Callisthenes in Arabic. I am preparing a critical edition with translation of what I coined the Quzmān redaction of the Arabic Alexander Romance.

47 Full title: Kitāb Siyar al-Mulūk al-musammā bi-Nihāyat al-Arab fì Akhbār al-Furs wa l-Arab ("Book of the Biographies of the Kings, entitled The Ultimate Aim, on the History of the Persians and Arabs"). My translations of this episode here are based on Cambridge University Library, Ms. Qq. 225, 69v-70r, of which no printed edition has yet been made. The equivalent passage can be found in the Teheran edition, 137-139.

48 See Pfister, "Das Nachleben der Überlieferung;" Stoneman, "Who are the Brahmans?," and Stoneman, "Naked Philosophers."

49 This may be a concept deriving from the reign of the $\delta$ เó $\delta 0 x o l$, the historical successors of Alexander.

50 See Doufikar-Aerts, Alexander Magnus Arabicus, 108 in particular note 63, 111.

51 Forefather of the Sassanids.

52 This historical dating of Bukht Nașr is obviously not compatible with this genealogy.

53 It is clear that the author alludes to the Arabians. The prediction in the Syriac apocalypses, claiming this rulership for the Byzantine Empire, seems to have been adapted in view of actual developments by the time of the author. 
His sword is his scourge upon the ones who disobey and he will be given victory over the ones who are hostile, and near and far away he will be feared. And a great deal of people will appear who will renounce the pleasures of this world and long for the hereafter. They bring about glory and are bestowed upon with victory and this will continue until there will rise among them jealousy, and they will develop great desires and there will be much greed, and evil will expand among them and their hearts will be filled with desire for the world and that will be their only concern. Then they will kill each other in such a war that the realm of the birds will fall down upon their realm at the coast of the $\mathrm{ea}^{55}$ and the world will witness a discord (fitna) as it has never witnessed before.

Then Alexander asked: 'What is the sign of the release of the Antichrist (al-Dajjāl)?' They answered: 'There will be many earthquakes, the powerful will be humbled and the despised will be raised and the wells will dry and there will be a shortage of water and people will go through much bloodshed and violate the inviolable (sacred).' Alexander exclaimed: 'Blessed are you, because to you are given moderateness and knowledge.' But the Brahmans said: 'Nay, blessed is the one whom God Almighty safeguarded from the temptations (fitna) of the world and who will leave the world unblemished. 56

Then Alexander continued:

'I want you to give me good advice.' They answered: 'What use can our morals be, since you are occupied with this world and greedy, without considering the End?' Alexander said: 'Tell me about the Hour ( $S \bar{a}^{\prime} a$ ) if you have knowledge about it.' They said: 'How can we have knowledge since God most High conceals it from all his creatures, only that certain evil things of mankind point to it.' He said: 'What are the portents (ashrāt $)$ of the Day of Judgement?' They said: 'The appearance of adultery and usurious interest and the satisfaction of men with men and of women with women. Moreover, there will be excessive arrogance and hypocrisy, the disappearance of fear and piety and the pursuit of worldly matters and the breakoff of kinship and the absence of fear of God from people's hearts.'

After this conversation Alexander asks the Brahmans what they would like to receive as a gift. 'Give us immortality', they reply. Since he cannot fulfill this wish, they ask him: 'If you are mortal yourself, why do you bother conquering the world when you to leave it to others when your time has come?' Alexander responds that he does not act for selfish reasons, and asks rhetorically: 'Don't you know that the waves of the sea would not move unless God sends upon them the winds that set them in motion? ${ }^{57}$

So far the Nihāya's description of Alexander's dialogue with the Brahmans, who are presented as a strictly ascetic nation..$^{58}$ The excerpt clearly includes a large portion of eschatological predictions. Although the initial predictions refer solely to the future rule of Persia, the rest of the prophecies have a general character. ${ }^{59}$ They put the history of the world in a holistic perspective of sovereignty and particular Is-

54 This seems to refer to Qur'an 5:54 in a slightly different wording.

55 This is a rather cryptic expression which may indicate that the sky falls down on the earth.

56 The term fitna, in the Islamic historical context often indicates the two early events of civil strife. It also means both temptation and discord.

57 See the original phrase in the Syriac version, Wallis Budge, The History of Alexander the Great, 92: "For just as the waves of the sea are not lifted up unless the wind blows upon them".

58 For the conversation with the Brahmans, see Doufikar-Aerts, "Give us Immortality."

59 The royal names can be identified as occurring in the Shahname, where Lohrāsb is mentioned as the father of Gushtāsp. In Shahrastānī’s Kitāb al Milal, Lohrāsb is the father of Bishtāsb, to whose 
lamic eschatology. There is no mention here of Gog and Magog, ${ }^{60}$ but by way of Alexander's conversation with the Brahmans we get a list of signs and portents of the End Times. It is remarkable in itself that all these eschatological issues have been incorporated in the story of the Brahmans, which is unique to the Nihaya, as far as I am aware. ${ }^{61}$ As to content, it is clear that the passage about the "sons of Isma'ill" living in the desert to whom God "will give power in the neighbouring lands", refers to the Arabians. With the "virtuous, God-fearing, devout, righteous and merciful man, who observes truthfulness and honesty" is obviously meant the Prophet Muhammad. Moreover, with these predictions Alexander is made a forerunner of these future events.

\section{The Signs of the End in the Mușannaf}

A second text that deserves our attention is from the Mușannaf ("Literary Work") by an early Islamic authority, 'Abd al-Razzāq al-San'ānī, who died in 827. ${ }^{62}$ 'Abd alRazzāq is also the transmitter of a biography of the Prophet Muhammad, Kitāb alMaghāzi ("The Book of Expeditions"), which was composed by his teacher Ma'mar ibn Rāshid (d. 770). In the Muṣannaf, 'Abd al-Razzāq presents exhaustive traditions about the Mahdi (the Islamic Messiah), the signs of the end of time, Gog and Magog, al-Masīh al-Dajjāl (the Antichrist) and the return of 'Isā ibn Maryam (Jesus, son of Mary). ${ }^{63}$

The Mușannaf reports of Gog and Magog that they do not die before they have produced an offspring of a thousand descendants. ${ }^{64}$ 'Abd al-Razzāq transmits the following information on the authority of his master, Ma'mar, from the father of Ibn Tâaūs. ${ }^{65}$ In Islamic tradition it is common - and even indispensable for the reliability of the information - that the source, and the chain of the transmitters (isna $\bar{a} d$ ) is mentioned. The afore-mentioned spokesman, Ibn Ṭāwūs's father, said:

Jesus, the son of Mary, will come down (on earth) as a guiding prayer-leader (imām), doing right and bringing justice. When he comes he will crush the cross and kill the swine and im-

court Zaradusht went in order to convince the king of his revelation. The identification with Bukht Nașr is unclear; was he a substitute for Zarathustra as another pagan character from a - to the author - nebulous and remote period?

60 The Gog and Magog episode can be found elsewhere in Alexander's history in the Nihāya, 76v. Also see Doufikar-Aerts, Alexander Magnus Arabicus, 157-158 and 163. Grignaschi, "La Nihāyatu-1'arab," 55-56.

61 See Doufikar-Aerts, "Give us Immortality."

62 Al-San'ānī, Kitāb al-Muṣannaf, no. 20843 and no. 20844, ed. al-Az'amī, vol. 2: 400-401.

63 Chapters in the Muṣannaf: Bāb qiyām al-Rūm; Bāb al-Dajjāl; Bāb nuzūl 'Isā ibn Maryam 'alayhima al-salām; Bāb qiyām al-Să'a. Al-San'ānī, ed. al-A'zami, vol 11, 385-403.

64 Al-San'ānī, Kitāb al-Mușannaf, no. 20810, ed. al-Az'amī, vol. 2: 385.

65 Al-San'ānī, Kitāb al-Mușannaf, no. 20843, ed. al-Az'amī, vol. 2: 400-401. 
pose the jizya [the taxes imposed upon non-Muslims], and the community of believers will be one. He will implement his command on earth until the lion will lay together with the cow, who will take him for a bull, and the wolf will be with the sheep, who will take him for the $\mathrm{dog}$, the poisonousness of venomous beasts will vanish and a man can lay his hand on the head of a snake and it does not harm him, and a girl can put a lion to flight, as a boy who puts a small dog to flight. An Arabian horse will have the value of twenty dirham [presumably, very cheap?] and a bull will cost so and so. The earth will return to its shape at the time of Adam, and a bunch of grapes will feed a whole group of people and the same goes for the pomegranate.

A slightly different account is transmitted in the Muṣannaf on the authority of Abū Hurayra. ${ }^{66}$

Both descriptions of the peaceful period initiated by the return of Jesus are reminiscent of the biblical prophet Isaiah's visions: “The wolf and the lamb will feed together, and the lion will eat straw like the ox, and dust will be the serpent's food. They will neither harm nor destroy on all my holy mountain, says the Lord." (Isa.iah 65:25) and "The wolf will live with the lamb, the leopard will lie down with the goat, the calf and the lion and the yearling together; and a little child will lead them." (Isaiah 11:6).

"Abd al-Razzāq also mentions various minor signs of the Hour. "Some of the signs of the Hour are; that knowledge will disappear and that ignorance will appear; that wine will be drunk; that adultery will spread about; that there will be a lack of males and a surplus of women, until there will be fifty women against one man."67

Regarding the upheaval at the end of time, 'Abd al-Razzāq quotes a book on the authority of 'Abd Allāh ibn 'Amr ibn al-'Ạṣ, in which it is said that there will be a great battle, during which the King of the Rūm will address his troops saying: "Whosoever has that wish, let him flee, God will bring a turn of fate (dabra) upon them. ${ }^{68}$ There will be a battle the likeness of which has never been witnessed - or will be seen - and when a bird passes above the heads of these men on the battlefield it will drop down dead, because of their stinking smell."69

This particular utterance appears not to be merely a topos. A similar statement can be found in relation to the Foetid Sea in one of the above-mentioned Syriac apocalyptic texts, the Neșhāna dileh d-Aleksandrōs. This passage was included also

66 Page 401, no. 20845. "Security will then cover the earth, so that lions will graze with camels, tigers with cattle, and wolves with sheep. Youth will play with snakes, and these will not harm them. He ['Isā] shall dwell in the earth for forty years, then he will die and Muslims will pray over him and bury him," translation Bijleveld, "Eschatology," 40.

67 Al-San'ānī, Kitāb al-Muṣannaf, no. 20801, ed. al-Az'amī, vol. 2: 381.

68 This is explained by the editor of the edition as hazima ("defeat").

69 No. 20813, page 387. It may be assumed that he is referring to the smell of the dead bodies. It is not clear whether the cryptic expression about the falling birds in the Nihāya implies something similar (see note 55 above). 
in the Arabic Alexander Romance, probably via an Arabic translation of the Neșhāna. In the Syriac “original”, the sea is described as follows:

Men are not able to come near to the Foetid Sea, neither can ships sail thereon, and no bird is able to fly over it, for if a bird should attempt to fly over it, it is caught and falls and is suffocated therein. Its waters are like pus; and if men swim therein, they die at once; and the leaves of the trees which are by its side are shrivelled up by the smell of these waters as though fire licked then. ${ }^{70}$

The Arabic version elaborates on this:

No bird can fly over it, because its water is like pus, which spreads a terrible smell, because this is the water through which God punished the people, who perished in the Flood. Their bodies and the bodies of the animals that died at that time lie in its depths. All the beasts and every living soul, birds as well as quadrupeds, perished in it and on its shore the trees remain without leaves, and moreover, they are fruitless and barren by reason of the stench and the nasty smell. You must know that no person, without exception, passes by or he will die and perish, because of the stench and the nasty smell. ${ }^{71}$

The element of the dead bodies added in the Arabic version gives the passage an even more ominous atmosphere by connecting the Foetid Sea with the Flood. Apparently, it circulated more widely, as is shown in a parallel description in the report of another author, 'Umāra ibn Zayd: "No bird can fly over [the Foetid Sea], because it would instantly fall down in it [...] due to its nasty smell and no living soul could come near without dying." 72

The characteristics, namely the birds flying over and dropping dead because of the stench, seem too odd and specific to be mere coincidental, which makes one ponder how they can crop up in these descriptions, without being somehow related.

\section{Predictions Written on the Gate of Gog and Magog}

A third report involving predictions concerning the end of time, an elaborate episode related to Gog and Magog, can be found in the above-mentioned Arabic Alexander Romance, Sirat al-Malik Iskandar. Like the description of the Foetid Sea,

70 Wallis Budge, The History of Alexander the Great, 145.

71 Sirat al-Malik Iskandar, ms. Maadi 14, 163r-163v.

72 My translation from Qișșat al-Iskandar, ms. Add. 5928, ff. 2-81, 59r. 'Umāra ibn Zayd (d. circa

815 ) is an early transmitter of a legendary biography of Alexander. See Doufikar-Aerts, Alexander Magnus Arabicus, 35-45. 
it derived from the Syriac Neșhāna. ${ }^{73}$ After a description of the horrible features and repulsive conduct of Gog and Magog, the text goes into some detail regarding Alexander Dhū 'l-Qarnayn's construction of the gate in the wall encircling Gog and Magog and a description he affixes to it: ${ }^{74}$

After he had completed [the building of] the gate he sealed, fortified and strengthened it; he made a coating of phylacteries, which neither iron, nor fire or anything else could erode. ${ }^{75}$

He wrote a Greek inscription on the gate in lead as he had done on the lighthouse in Alexandria; ${ }^{76}$ it said: 'In all ages, times and years the nations [Gog and Magog] will attempt to open the gate. They will try hard, but will not achieve unlocking it. They will even lick it with their tongues that are sharp as a snake's tongue, but they will not be able to unfasten it until the time has arrived when God Almighty commands that it shall be opened. This will happen in the year 864 of the final thousand years, when destruction will take place with the extinction of these nations, and the annihilation of the greedy lickers ${ }^{77}$ from the whole world, until there is no one left to blow on the fire, neither a dog to water against the wall. At that time sins and crimes will be numerous and the Lord's anger with their deeds will come down upon them. God will send unto them the kings of Yājūj and Mājūj.'

They will come forth from their remote habitations and they will gather at the gate with their horses and weaponry. They will cry out God's great name and the gate which was made will crumble down; they will not even need a key. The evildoers will come out escaping through the gate. The multitude of their horses' hoofs that run over the threshold of the gate will make the doorsill sink down a large span, and likewise will the gate's upper frame be destroyed by the track of the spearheads. When Yājūj and Mājūj break out this will heralded in all directions of the land of the Rūm, the Persians and Arabians. Then twenty-four thousand kings ${ }^{78}$ will come together and destroy a huge number of people until the ground will have become invisible because of the awful bloodshed upon it. Then also the impure nations ${ }^{79}$ (?) will break forth and the people will [try to] escape from them.

Only a few people will deny what I say. If they do not believe me, let them consider the prophecies of Irmiyā (Jeremiah) the prophet. This is another sign, which God has made behind the gate; a huge stone dripping blood on the rocks. The people of these places will come to wash

73 Wallis Budge, The History of Alexander the Great, 144-161. This Arabic Quzmān-redaction of the Alexander Romance, Sirat al-Malik Iskandar, is for the greater part based on the Syriac Alexander Romance, but it includes parts of the Syriac Neșhāna as well.

74 For the translation of this episode, see Doufikar-Aerts, Alexander Magnus Arabicus, 158-160.

75 On this phenomenon, see Aerts, "Alexander's Wondercoating," 159-167.

76 See above, the illustration on the worldmap from the Mojmal al-Tawārikh, which demonstrates the dominant place and connectedness of the two constructions. Also see Doufikar-Aerts, "Alexander the Great and the Pharos."

77 The word is spelled differently in the manuscripts and may be corrupt; the variant al-lähisūn (licking, devouring) seems to make sense in this context.

78 A chiliad of the twenty-four kings spoken of at the initial confinement. In Islamic tradition, like we have seen in the Mușannaf, it is said that the men of Gog and Magog produce at least a thousand offspring before they die.

79 This is not fully clear; the Neșhāna (Wallis Budge, The History of Alexander the Great, 155) says: "the kingdom of the Greeks", whereas the Ethiopic text (Wallis Budge, Life and Exploits of Alexander the Great, 241) has "the royal armies". The word "armies" is probably based on Arabic juyūsh. However, the Arabic manuscripts have junūs - probably a corruption - as a somewhat uncommon plural of jins, race. 
their heads with this blood and drink from it. Then they will return to their kinfolk. Thus will God shed the blood of men on the earth, just as the blood which is spilled on the rock. ${ }^{80}$

Gog and Magog licking the Wall in order to demolish it is a familiar element that we already encountered in the Javanese poem above, in which Juja-Makjuja tried to destroy the chains that bind him, by using his tongue. Eventually, he was put in chains that he could not lick away completely, due to the prayers of the faithful. The sharp tongues of Gog and Magog were not part of the Syriac tradition; they first appear in the Arabic texts building on it. ${ }^{81}$ In the wake of the expansion of Islam into far away regions this feature of Gog and Magog was transferred over centuries and continents to survive, amongst other places, in the poetry of the Indian archipelago. A detailed analysis of other features of this passage and an in-depth comparison with its Syriac versions unfortunately lie outside the scope of this article. Here it must suffice to point to the characteristics of Gog and Magog, in particular the great number of their hordes, their reputation of annihilators and the crumbling down of the Wall.

\title{
5 End Time Predictions in Dürr-i Meknūn
}

In the final section, I will show the intertwined character of the Gog and Magog tradition through a summary of its elements as contained in a fifteenth-century cosmography, entitled Dürr-i Meknūn ("Hidden Pearl”) and composed by Aḥmed Bīcān in Ottoman Turkish. ${ }^{82}$

\begin{abstract}
At the end of time, 'Issā (Jesus) will receive a revelation and he will bring together the believers at Mount Tuurr (Sinai). Then two brothers, Gog and Magog, and their companions will tear down the Wall. They have small bodies and small eyes and drooping ears. They will spread all over the earth and roast and eat the people and the animals they find on their way. The first group drinks all the sweet water and the second all the brackish water and the rest can only lick the mud that is left in the swamps. The earth will be covered by them to the extent that birds find no place to land other than on their heads. The shortage of food will be so severe that one sheep is auctioned for a thousand pieces of gold. 'Isā encourages the people with good advice. Gog and Magog shoot arrows to the heavens. ${ }^{83}$ When 'İsa prays to the Almighty, the believers say, 'Amen', and then the Almighty sends an army in the shape of a black horse. The army defeats Gog and Magog. Birds with camel necks drop the bodies into the sea. Then everything becomes cheap [!] and 'Īsā will crush the idols and he performs the pilgrimage together with the Așhāb al-Kahf, the 'people of the cave'. Then he goes to Medina and marries an Arabian
\end{abstract}

80 My translation of the Sirat al-Malik Iskandar, ms. Maadi 14, 173r. The text was transmitted in Coptic circles, but has a hybrid Christian and Islamic character.

81 See Doufikar-Aerts, "Dogfaces, Snake-tongues, and the Wall against Gog and Magog," 47-48.

82 The text was published in an astounding luxury edition by Kaptein, Ahmed Bican Yazıcıŏlu.

83 This is reminiscent of Ezekiel 39:3. Shooting arrows into the air is a pre-islamic sooth-saying practice. 
woman and has daughters with her. He will be Sultan for forty years, and then God will bestow upon him His grace and call him to heaven. ${ }^{84}$

Some of the elements in this apocalyptic text are unusual, but other elements, such as depicting Gog and Magog with drooping ears, occur quite regularly, such as in the descriptions by 'Umāra ibn Zayd and Abū 'Abd al-Malik ${ }^{85}$, but also in the Persian tradition, as can be seen in a lithograph edition of the Khamse by the famous twelfth century Persian poet Nezamì Ganjāvī (1141-1209). ${ }^{86}$ The vision of the End Times in the Dürr-i Meknūn combines an interesting mix of elements. The prominent role of 'Īsā is worth noting. The prophet Jesus forms an integral part of Islamic eschatological visions. Within this framework, he is depicted as the defender of iconoclasm by his destruction of idols. The People of the Cave (sometimes also called the Sleepers or the Companions of the Cave), mentioned in the Qur'anic verses 18:9-26, are said to be 'Īsā's companions on his pilgrimage to Mecca. In Islamic exegesis the Așhāb al-Kahf or Sleepers of the Cave are mostly thought of as being adherents of Christianity, who for that reason were persecuted during the reign of Daqiyānūs, the Roman emperor Decius (201-251 CE). They appear not only in the Islamic tradition but also in eastern and western Christianity as the "Seven Sleepers of Ephesus", who are honoured as martyrs. ${ }^{87}$

In this respect it should also be noted that according to the Irshād al-Qulūb, a treatise on ethics written by the fourteenth-century Shi'a scholar Hasan Ibn Abi l-Hasan al-Daylamī, the Companions of the Cave are to return to assist the Mahdi [Messiah]. ${ }^{88}$ Furthermore, as 'Isā is described as making the pilgrimage to Mecca, it appears that at the end of time, he is part of the umma, the community of Muslim believers, or that all Christians, with him, have joined the umma.

The innumerable multitude of Gog and Magog's hordes is visualised here by the image of birds finding nowhere to land, except on the heads of the marauders, because they completely cover the place. The image can be traced back to the biblical descriptions quoted above: Ezekiel's description of Gog “cover[ing] the land like a cloud", and the Book of Revelation's saying about Gog and Magog that "their number is like the sand of the sea”.

84 My paraphrase on the basis of Kaptein's Dutch translation of manuscript pages 152r-152v of Dürri Meknūn, Eindtijd en Antichrist (ad-Dağğăl) in de Islam, Eschatologie bij Ahmed Bīcān, 187-189. 85 'Umāra ibn Zayd, Qișșat al-Iskandar and Abū 'Abd al-Malik (possibly second half of the ninth cent.), Qișsat Dhī 'l-Qarnayn, see Doufikar-Aerts, Alexander Magnus Arabicus, 166-167. Also see above, note 72 .

86 Reproduction in Seyed-Gohrab, Doufikar-Aerts, McGlinn, eds., Gog and Magog, The Clans of Chaos, 122. For a description of the physical characteristics of Gog and Magog, see Doufikar-Aerts, Alexander Magnus Arabicus, §3.6.2, 163-168.

87 There is a wide-spread literature on martyria in Syriac, Greek and Latin as well as pictorial manifestations. A number of relics and several shrines were venerated as the assumed Cave.

88 Irshād al-Qulūb ilā l-Ṣawāb al-Munjī man 'Amila bi-hi min Alim al-'Iqāb. In Shi'a believe the Mahdi is the twelfth Imām. 
Lastly, it goes without saying that the release of Gog and Magog in the Islamic canon is one of the ominous signs of the imminent end of time.

These four examples of the visions of the end of time may have shown that the Islamic tradition of the Gog and Magog motif is rooted in a long line of transmissions. Even nowadays, the tradition is kept very much alive in a wealth of popular books and on the internet. ${ }^{89}$ Whilst the motif's modern development has not been the subject of this investigation, it is very clear that the eschatological tradition, and in particular the motif of Gog and Magog, has in both literary and oral form continued to serve a function during the last centuries in the struggle against imperialism and colonialism, and particularly in cases of political injustice. In his analysis of the Javanese poem discussed above, Edwin Wieringa has shown that in the nineteenth century, such eschatological motifs became a way to oppose the "other", the Christian coloniser. Thus the wicked Juja-Makjuja is presented as a grandson of Jesus, who figures in the poem as the Nabi Ngisa, "Prophet Jesus". According to Wieringa, "[t]here can be no doubt that Juja-Makjuja represents the barbarian Dutch colonial administration here". ${ }^{90}$

In nineteenth-century North Africa, Gog and Magog similarly became a factor in the belief that "the Christians", namely the French colonisers, would be expelled from their lands at the arrival of the "Master of the Hour". According to the predictions of Kabylian marabouts, at least as recorded by the Dutch Lieutenant C. M. de Jong van Rodenburgh in 1855, "the Arabs ${ }^{91}$ await this messianic figure" and "the gate will be opened and a coarse nation, which is held locked up by this gate behind two huge mountains in inner Africa, will assault the living. The total destruction [...] preludes the end of time." 92 The coarse nation, evidently a reference to Gog and Magog, has been geographically transposed to the inner lands of Africa, another terra incognita for the Kabylians, and an equally convincing Magogistan.

My reconstruction of key phases in the development and spread of the Gog and Magog theme in relation to Alexander Dhū 'l-Qarnayn shows that crossing borders was a continuous and "medieval world"-scale process. The narration has lately been resumed on the world wide web, as an antique mindset garbed in modern apparel, showing that the fascination for Gog and Magog has not left the minds and consciousness of religious communities, nor those of scholars.

89 See Haddad and Smith, "The Anti-Christ and the End of Time," and Seyed-Gohrab, DoufikarAerts, McGlinn, eds., Gog and Magog.

90 Wieringa, "Juja-Makjuja as the Antichrist," 144.

91 The lieutenant probably did not distinguish the Kabylian Berbers from the Arab-speaking population, or he used the word Arabs for Muslims.

92 Doufikar-Aerts, “Dogfaces, Snake-tongues, and the Wall against Gog and Magog,” 37. I thank my brother, Remieg Aerts, who long ago brought to my attention the article by de Jong van Rodenburgh in De Gids. 


\section{Bibliography}

\section{Cited Manuscripts}

Abū 'Abd al-Malik, Qișșat Dhī'l-Qarnayn, Rabat, Bibliothèque nationale, ms. D 1427.

Sirat al-Malik Iskandar, Cairo, ms. Maadi 14. Pseudo-Așmā'̄, Kitāb Siyar al-Mulūk, Cambridge, ms. Qq. 225.

Topkapı Sarayı Müzesi Kütüphanesi, ms. A. 3346, fols. 3b-4.

'Umāra ibn Zayd, Qișșat al-Iskandar, London, British Library, Arabic ms. Add. 5928.

\section{Primary Sources}

'Abd al-Razzāq al-Ṣan'ān, Kitāb al-Muṣannaf. Vol. 2, edited by Habib al-Rahman al-Az'amī, Beirut, 1970.

Die Apokalypse des Pseudo-Methodius. Die älteste griechische und lateinische Übersetzungen. Edition of the Greek text by Willem J. Aerts and edition of the Latin text by George A.A. Kortekaas. Corpus Scriptorum Christianorum Orientalium (CSCO), I introduction and indices, vol. 569, tom. 97 and II, Commentary, Lexicon and Indices, vol. 570, tom. 98. Louvain: Peeters Publishers, 1998.

Ahmed Bican Yazıcıoğlu. Dürr-i meknûn. Kritische Edition mit Kommentar. Edited by Laban Kaptein. Asch: Privately published, 2007.

Damīrī, Muḥammad ibn Mūsā Kamāl al-Dīn al-, Ḥayāt al-Ḥayawān (“Lives of the Animals”), ed. M.T. Houtsma, 1305 H, Cairo, 1887.

Grignaschi, Mario, La Nihāyatu-l-'arab fĩ akhbāri-l-Furs wa-l-'Arab (première partie). Bulletin d'études orientales 22, (1969): 15-67.

Ibn Hishām, Sīrat al-Nabī, Fathi Anwar al-Danuli, Cairo (s.d.)

Ibn Kathīr, 'Imād al-Dīn Ismāeīl ibn 'Umar. Al-Bidāya wa 'l-Nihāya, Beirut-London: Dar al-Kutub al alIslamiya, 14 vols. I, London-Beirut, 1985-1988.

Flavius Josephus with an English Translation in Nine Volumes, vol. 3: The Jewish War, Books IV-VII, edited by Henry St. John Thackeray. Cambridge/Mass.: Harvard University Press, 1961.

Mojmal al-Tawārikh, ms. pers. Cod. Heid. orient. 118, fols. 258b-259a, in the University Library of Heidelberg. http://www.iranicaonline.org/articles/mojmal-al-tawarik, figure 8, [accessed 22 April 2019]

Pseudo-Așmā'ī, Nihāyat al-Arab fí Akhbār al-Furs wa 'l-'Arab, Muhammad Taqī Dānish Tharwa, Teheran, 1955.

Wallis Budge, E. A. The History of Alexander the Great, being the Syriac Version. Edited from Five Manuscripts of the Pseudo-Callisthenes, with an English Translation, Accompanied by a Historical Introduction on the Origins and the Various Oriental and European Versions of the Fabulous History of Alexander, with Notes, Glossary, Appendixes, Variant Readings, and Indexes. Cambridge: Cambridge University Press, 1889 (reprinted Amsterdam: APA-Philo Press, 1976).

Wallis Budge, E. A. Life and Exploits of Alexander the Great. Ethiopic Histories of Alexander by the Pseudo-Callisthenes and other Writers. London: C.J. Clay and Sons, 1896.

Zuwiyya, Z. David. Islamic Legends Concerning Alexander the Great. Taken form Two Medieval Arabic Manuscripts in Madrid. Binghamton, NY: Global Publications, 2001. 


\section{Secondary Literature}

Aerts, Willem, J. “Alexander's Wondercoating." In Media Latinitatis. A Collection of Essays to Mark the Occasion of the Retirement of L.J. Engels, edited by Renée I. A. Nip, Hans van Dijk, Elisabeth M. C. van Houts, Corneille H. J. M. Kneepkens, George A. A. Kortekaas, 159-167. Vol. 28, Instrumenta Patristica. Turnhout: Brepols, 1996.

Aerts, Willem, J. "Gog, Magog, Dogheads and other Monsters in the Byzantine World." In Gog and Magog: The Clans of Chaos in World Literature, edited by Asghar A. Seyed-Gohrab, Faustina C. W. Doufikar-Aerts and Sen McGlinn, 23-36. Amsterdam, West Lafayette: Rozenberg Publishers \& Purdue University Press, 2007.

Bekkum, Wout J. van. A Hebrew Alexander Romance According to Ms. London, Jew's College, no. 145. Edited, translated and introduced. Louvain: Peeters Publishers, 1992.

Bekkum, Wout J. van. A Hebrew Alexander Romance According to Ms. Hev. 671.5 Paris, Bibliotheque Nationale. Edition, translation and introduction. Groningen: Styx Publications, 1994.

Bijleveld, Willem A. "Eschatology: Some Muslim and Christian Data." Islam and Christian-Muslim Relations 15/1 (2004): 35-54.

Bohas, Georges, Abderrahim Saguer and Ahyaf Sinno eds., Le Roman d'Alexandre à Tombouctou. Histoire de Bicornu. Le manuscrit interrompu. Bibliothèque Commémorative Mamma Haidara. Edition and French translation, Lyon: Actes Sud/École normale supérieure de Lyon, 2012.

Bøe, Sverre. Gog and Magog: Ezekiel 38-39 as Pre-text for Revelation 19:17-21 and 20:7-10. Wissenschaftliche Untersuchungen zum Neuen Testament, 2. Reihe. Tübingen: Mohr Siebeck, 2001.

Coleman, Lyman. An Historical Textbook and Atlas of Biblical Geography. 1st edition, Philadelphia: J. B. Lippincott, Grambo \& Co, 1854.

Cross, Samuel, H. "The Earliest Allusion in Slavic Literature to the Revelations of PseudoMethodius." Speculum 4/3 (1929): 329-339.

De Jong van Rodenburg, C. M. De Gids, 19, n.s. 8/2 (1855) 447-467.

Donzel, Emeri van, and Andrea Schmidt, eds., Gog and Magog in Early Eastern Christian and Islamic Sources. Sallam's Quest for Alexander's Wall. Leiden, Boston: Brill, 2010.

Doufikar-Aerts, Faustina C.W. "Alexander the Great and the Pharos of Alexandria in Arabic Literature." In The Problematics of Power: Eastern and Western Representations of Alexander the Great, edited by Margaret Bridges and J. Christoph Bürgel, 191-202. Bern: Peter Lang, 1996.

Doufikar-Aerts, Faustina C.W. "Dogfaces, Snake-tongues, and the Wall against Gog and Magog." In Gog and Magog: The Clans of Chaos in World Literature, edited by Asghar A. Seyed-Gohrab, Faustina C.W. Doufikar-Aerts and Sen McGlinn, 37-52. Amsterdam, West Lafayette: Rozenberg Publishers \& Purdue University Press, 2007.

Doufikar-Aerts, Faustina C.W. Alexander Magnus Arabicus. A Survey of the Alexander Tradition Through Seven Centuries, from Pseudo-Callisthenes to Șūrī. Mediaevalia Groningana 13 n.s. Peeters Publishers: Louvain, 2010.

Doufikar-Aerts, Faustina C.W. "Alexander in Medieval Arab Minds: Archetype of Kings, Magnificent Warrior, and Custodian of Philosophy and Divine Principles." Chapter 15 in Alexander the Great in World Culture. A Companion to World Literature. Cambridge: Cambridge University Press, forthcoming 2020.

Doufikar-Aerts, "Give us Immortality." In Prophets, Viziers and Philosophers: Wisdom and Authority in Early Arabic Literature (8th-11th), ed. Emily Cottrell, Groningen: Barkhuis, forthcoming 2020.

Garstad, Benjamin. Apocalypse of Pseudo-Methodius. An Alexandrian World Chronicle. Vol. 14, Dumbarton Oaks Medieval Library. Cambridge/Mass.: Harvard University Press, 2012. 
Gerritsen, Willem, P. “Gog and Magog in Medieval and Early Modern Western Tradition.” In Gog and Magog: The Clans of Chaos in World Literature, edited by Asghar A. Seyed-Gohrab, Faustina C. W. Doufikar-Aerts and Sen McGlinn, 9-22. Amsterdam, West Lafayette: Rozenberg Publishers \& Purdue University Press, 2007.

Gow, Andrew. "Gog and Magog on mappaemundi and Early Printed World Maps: Orientalizing Ethnography in the Apocalyptic Tradition." Journal of Early Modern History 2, no. 1 (1998): 6188.

Gow, Andrew. "Excerpt from Gog and Magog on mappaemundi and Early Printed World Maps: Orientalizing Ethnography in the Apocalyptic Tradition": http://www.myoldmaps.com/early-medieval-monographs/gog-and-magog-on-mappaemund.pdf, [accessed 22 April 2019]

Haddad, Yvonne, Y. and Jane I. Smith. "The Anti-Christ and the End of Time in Christian and Muslim Eschatological Literature." The Muslim World 100 (2010): 505-529.

Jouanno, Corinne. Naissance et métamorphoses du Roman d'Alexandre. Paris: Éditions CNRS, 2002.

Kaptein, Laban. Eschatologie bij Aḥmed Bīcān (d. ca. 1466). Phd dissertation, University of Leiden, 1997.

Miller, Konrad, Library of the Congress, "Weltkarte des Idrisi vom Jahr $1154 \mathrm{n}$. Ch., Charta Rogeriana", https://www.loc.gov/resource/g3200.ct001903/?r=0.023,0.279,0.295,0.123,0 [accessed 22 April 2019]

Moennig, Ulrich. "Alexander the Great in Ancient, Byzantine and Modern Greek Tradition." In $A$ Hero Without Borders: 1, Fictional Storytelling in the Medieval Eastern Mediterranean and Beyond, edited by Carolina Cupane and Bettina Krönung, 59-189. Brill's Companions to the Byzantine World. Leiden, Boston: Brill, 2016.

Pfister, Friedrich. "Das Nachleben der Überlieferung von Alexander und den Brahmanen." Hermes 76 (1941): 143-168.

Pritchard, Roger, T. The History of Alexander's Battles. Historia de preliis. The J1 version. Vol. 34, Medieval Sources in Translation. Pontifical Institute of Mediaeval Studies: Toronto, 1992.

Reinink, Gerrit, J. "Alexander the Great in Seventh-Century Syriac 'Apocalyptic' Texts." Byzantinorossica 2 (2003): 150-178.

Ricklefs, Merle. The Seen and Unseen Worlds in Java: History, Literature and Islam in the Court of Pakubuwana II. St Leonards: Allen \& Unwin; Honolulu: University of Hawai'i Press, 1998.

Sanson, Guillaume. Description General du Globe Terrestre et Aquatique en Deux-Plan-Hemispheres. Paris: H. Jaillot, 1674.

Seyed-Gohrab, Asghar A., Faustina C.W. Doufikar-Aerts, and Sen McGlinn, eds. Gog and Magog. The Clans of Chaos in World Literature. Amsterdam, West Lafayette: Rozenberg Publishers \& Purdue University Press, 2007. Second edition: Embodiments of Evil, Gog and Magog: Interdisciplinary Studies of the 'Other' in Literature \& Internet Texts. Leiden: Leiden University Press, 2011.

Stoneman, Richard. "Who are the Brahmans? Indian Lore and Cynic Doctrine in Palladius' De Brahamanibus and its Models." Classical Quarterly 44 (ii) (1994): 500-510.

Stoneman, Richard. "Naked Philosophers. The Brahmans in the Alexander Historians and the Alexander Romance.” Journal of Hellenic Studies 115 (1995): 99-114.

Trumpf, Georg, "Pap. Berl. 21266 - Ein Beleg für die historische Quelle des griechischen Alexanderromans." Zeitschrift für Papyrologie und Epigraphik, 155 (2006): 85-90.

Wieringa, Edwin. "Juja-Makjuja as the Antichrist in a Javanese End-of-Time Narrative." In Gog and Magog: The Clans of Chaos in World Literature, edited by Asghar A. Seyed-Gohrab, Faustina C. W. Doufikar-Aerts, and Sen McGlinn, 123-152. Amsterdam, West Lafayette: Rozenberg Publishers \& Purdue University Press,, 2007. 